\title{
Evaluation of Physical Properties of Clays Mixed with Silica Sand
}

\author{
(Penilaian Ciri-ciri Fizikal Tanah Liat Dicampur Pasir Silika)
}

A. Akbar Firoozi*, M.R. Taha, A. Asghar Firoozi \& Tanveer A. Khan

ABSTRACT

This study examined the effects of heat treatment on two types of clays mixed with silica sand under laboratory conditions. Soils were subjected to three varied temperatures, i.e. 100, 250 and $500^{\circ} \mathrm{C}$. The soil properties studied were Atterberg's limits, optimum water content and unconfined compressive strength. Experimental results showed that the temperature greater than $100^{\circ} \mathrm{C}$ resulted in a reduction in Atterberg's limits, optimum water content and unconfined compressive strength. For illite and silica mixture heating the soils at $500^{\circ} \mathrm{C}$, liquid limit, plastic limit, optimum water content and unconfined compressive strength were reduced to $12 \%, 0 \%, 40 \%$ and $0 \%$, and for kaolinite and silica mixture the above characteristics reduced to $18 \%, 0 \%, 50 \%$ and $0 \%$ respectively when matched to soil specimen's properties at ambient temperature. Whereas maximum dry density for illite and kaolinite increased by $5 \%$ and $8 \%$ respectively for the two clays.

Keywords: Clay; heat treatment; Atterberg limits; optimum water content; unconfined compressive strength

ABSTRAK

Kajian ini mengkaji rawatan kesan dari rawatan haba ke atas dua jenis tanah liat dicampur dengan pasir silika di bawah keadaan makmal. Tanah melalui tiga suhu berbeza, iaitu 100, 250 dan $500^{\circ} \mathrm{C}$. Sifat tanah yang dikaji ialah had Atterberg, kandungan air optimum dan kekuatan mampatan bebas. Hasil eksperimen menunjukkan bahawa suhu melebihi $100^{\circ} \mathrm{C}$ mengakibatkan satu penurunan di dalam had Atterberg, kandungan air optimum dan kekuatan mampatan bebas. Untuk campuran ilit dan silica, memanaskan tanah pada suhu $500^{\circ} \mathrm{C}$ menyebabkan had cecair, had plastik, kandungan air optimum dan kekuatan mampatan bebas dikurangkan kepada 12\%, 0\%, 40\% dan 0\%, dan untuk campuran kaolinit dan silica, ciri-ciri di atas mengurang kepada 18\%, 0\%, 50\% dan 0\% masing-masing apabila dipadankan dengan ciri-ciri spesimen tanah di suhu ambien. Manakala ketumpatan kering maksimum untuk ilit dan kaolinit dinaikkan sebanyak 5\% dan 8\% masing-masing untuk dua tanah liat ini.

Kata kunci: Tanah liat; rawatan haba; Had Atterberg; kandungan air optimum; kekuatan mampatan bebas

INTRODUCTION

Temperature modifies the physical and mechanical properties of clays. When the clayey soils are treated with heat, some of the changes in properties are permanent. The huge fires in the forests across the world have brought the thought to measure the effect of heat on clayey soils (Alcocer 1993 and William 1997). Many researchers have investigated the effect of heat treatment on the clayey soils. Mitchell (1969) showed that the heat treatment changed the physical properties of the clayey soils such as angle of friction, cohesion and strength. Joshi et al. (1994) investigated the effect of the heat treatment on the strength of clayey bricks at temperatures ranging from 300 to $700^{\circ} \mathrm{C}$. And it was found that an increase in strength was accompanied with the increase in temperature. Yang and Farouk (1995), Akinmusuru (1994), and Ma and Hueckel (1992) investigated the effect of heat on the thermal conductivity of clayey bricks. Tanaka et al. (1997) evaluated the stress-strain behaviors of the remodeled illite clay at different temperatures. It was found that the peak undrained strength was increased due to the development of reduced pore water pressure during testing.
Michot et al. (2008) found strong relation between the thermal conductivity of kaolin and the temperature of heat treatment. Heat treatment temperature less than $1050^{\circ} \mathrm{C}$ yielded thermal conductivity of less than $0.3 \mathrm{~W} \mathrm{~m}^{-1} \mathrm{~K}^{-1}$. Whereas the temperature of heat treatment greater than $1050^{\circ} \mathrm{C}$ produced thermal conductivity of up to $3 \mathrm{~W} \mathrm{~m}-1 \mathrm{~K}^{-1}$. C. Vizcayno et al. (2009) compared the results between pozzolanic activity of metakaolin (MK) obtained by thermal treatment at $700^{\circ} \mathrm{C}$ for 1 hour and amorphous kaolin produced by mechanochemical treatment in a Herzog oscillating mill for 15-120 minutes. It was found that the pozzolanic index and the mechanical resistances acquired by grinding were alike to the thermal treatment.

Bayram et al. (2010) evaluated the effect of heat treatment on bentonite $(\mathrm{CaB})$. Bentonite was heated for two hours for temperatures ranging from 100 to $1100^{\circ} \mathrm{C}$. It is evident that Bentonite lost adsorbed and hydration water at $300^{\circ} \mathrm{C}$, dehydroxylation took place between the temperature of 300 to $750^{\circ} \mathrm{C}$ and water was completely removed at $900^{\circ} \mathrm{C}$.

The research has been mainly focused on illite or kaolinite, where as in this study mixtures of these soils with 
silica sand were evaluated. Acknowledging that in the natural form the soils are rarely pure clay minerals. The main objective of this study was to investigate the effect of temperature on physical properties of clayey soils. The parameters investigated in this study include Atterberg limits, optimum water content and unconfined compressive strength.

\section{EXPERIMENTAL PROCEDURE}

The clay minerals used in this study were kaolinite and illite. Silt which was mixed with clay minerals in the present study was silica sand with fine grained particles $(45 \mu \mathrm{m})$. Kaolinite and illite clay minerals were obtained from Kaolin (Malaysia) factory under the trade name of "S-300" and "KM800" respectively. Table $1 \& 2$ present the properties of kaolinite and illite, which were determined during this study by performing a series of geotechnical laboratory experiments using procedures recommended by relevant ASTM standards. In Figure 1, Figure 2 and Figure 3, scanning electronic microscope (SEM) images are given which show the kaolinite, illite and silica sand layers.

TABLE 1. Physical property of materials

\begin{tabular}{cccc}
\hline & Kaolinite & & Illite \\
\hline Moisture content & Below $1.5 \%$ & Moisture content & Below $2.0 \%$ \\
$\mathrm{pH}$ & 4.0 & $\mathrm{pH}$ & 4.5 \\
100 mesh residue & Below $10 \%$ & 325 mesh residue & Below $3.0 \%$ \\
60 mesh residue & Below 0.5\% & Average particle size & $2.5-5.0 \mu \mathrm{m}$ \\
Specific gravity (Gs) & 2.723 & Specific gravity (Gs) & 2.701 \\
ASTM D854 & & ASTM D854 & \\
\hline
\end{tabular}

TABLE 2. Chemical compositions of clay minerals and silica sand

\begin{tabular}{cccccc}
\hline \multicolumn{2}{c}{ Kaolinite } & \multicolumn{2}{c}{ Illite } & \multicolumn{2}{c}{ Silica Sand } \\
\hline Formula & Concentration (\%) & Formula & Concentration (\%) & Formula & Concentration (\%) \\
\hline $\mathrm{SiO}_{2}$ & 85.76 & $\mathrm{SiO}_{2}$ & 29.43 & $\mathrm{SiO}_{2}$ & 97.29 \\
$\mathrm{Al}_{2} \mathrm{O}_{3}$ & 9.11 & $\mathrm{Al}_{2} \mathrm{O}_{3}$ & 52.37 & $\mathrm{Al}_{2} \mathrm{O}_{3}$ & 2.71 \\
$\mathrm{Fe}_{2} \mathrm{O}_{3}$ & 0.38 & $\mathrm{Fe}_{2} \mathrm{O}_{3}$ & 1.85 & - & - \\
$\mathrm{K}_{2} \mathrm{O}$ & 1.34 & $\mathrm{~K}_{2} \mathrm{O}$ & 8.21 & - & - \\
$\mathrm{Heat} \mathrm{loss}$ & 3.41 & $\mathrm{MgO}$ & 1.76 & - & - \\
- & - & $\mathrm{TiO}_{2}$ & 1.36 & - & - \\
- & - & $\mathrm{Heat} \mathrm{loss}$ & 5.02 & - & - \\
\hline
\end{tabular}

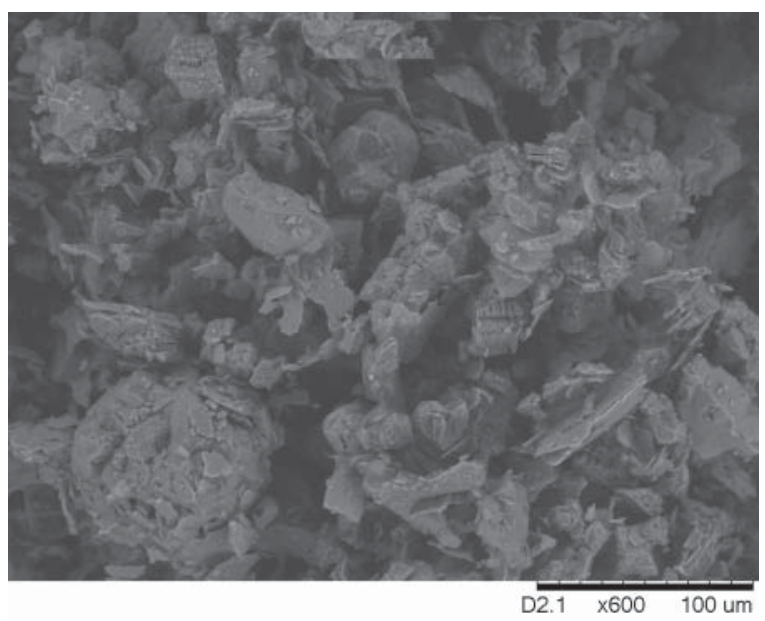

FIGURE 1. Kaolinite particles under SEM

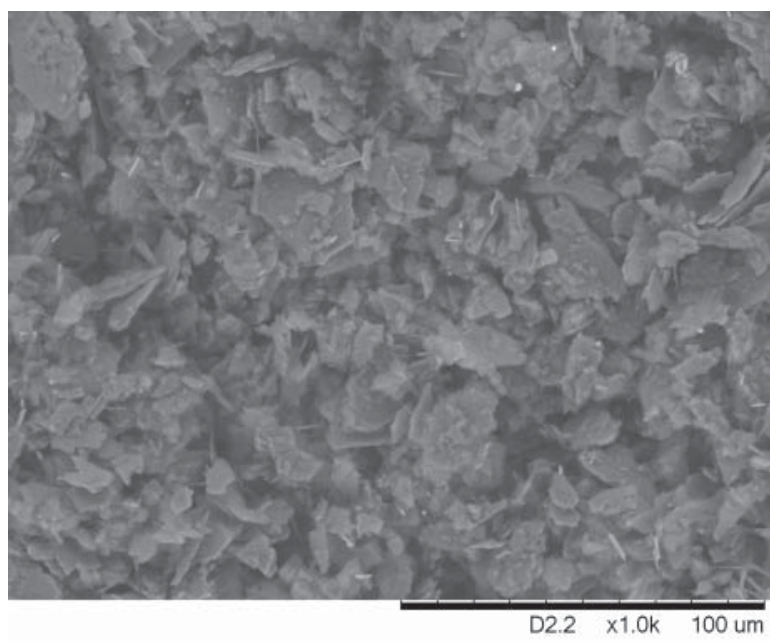

FIGURE 2. Illite particles under SEM 


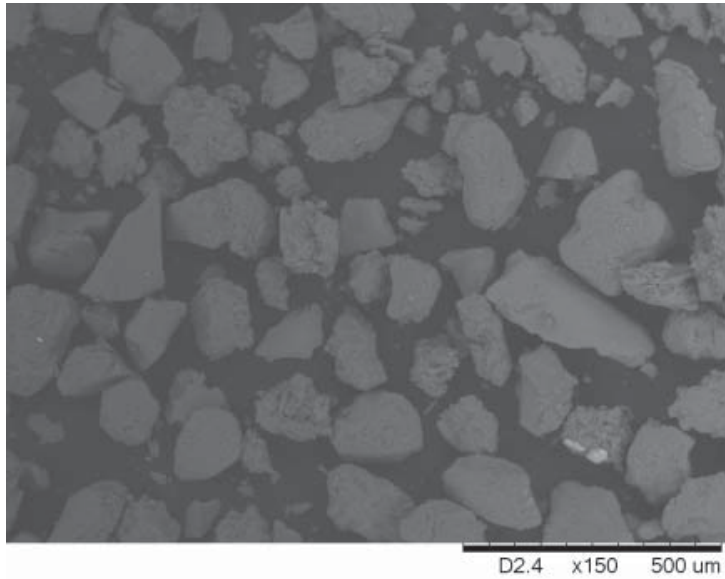

FIGURE 3. Silica Sand particles under SEM

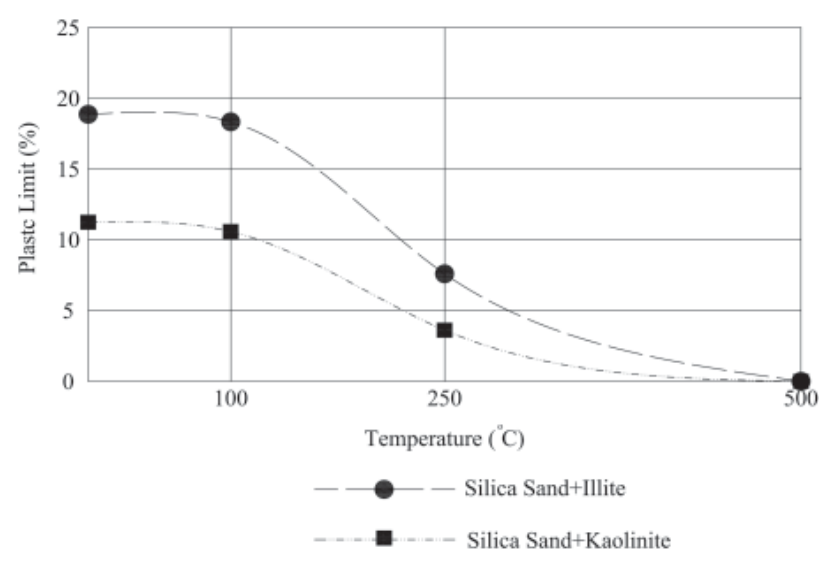

FIGURE 5. Effect of heat treatment on plastic limit

decreased by more than $50 \%$ for both samples. Beyond $250^{\circ} \mathrm{C}$, liquid limit appeared to get less affected by temperature, rise to reach a value of about $5 \%$ for the two specimens.

Figure 6 and Figure 7 shows the effect of temperature treatment on optimum water content and maximum dry density, respectively. Optimum water content decreased with increasing temperature, though it was less affected by temperature below $100^{\circ} \mathrm{C}$. At a temperature of $500^{\circ} \mathrm{C}$ the optimum water content of illite and kaolinite reduced to $40 \%$ and 50\% respectively. A rise in maximum dry density was observed for both the clays reaching the increase up to $5 \%$ and $8 \%$ for illite and kaolinite respectively at $500^{\circ} \mathrm{C}$.

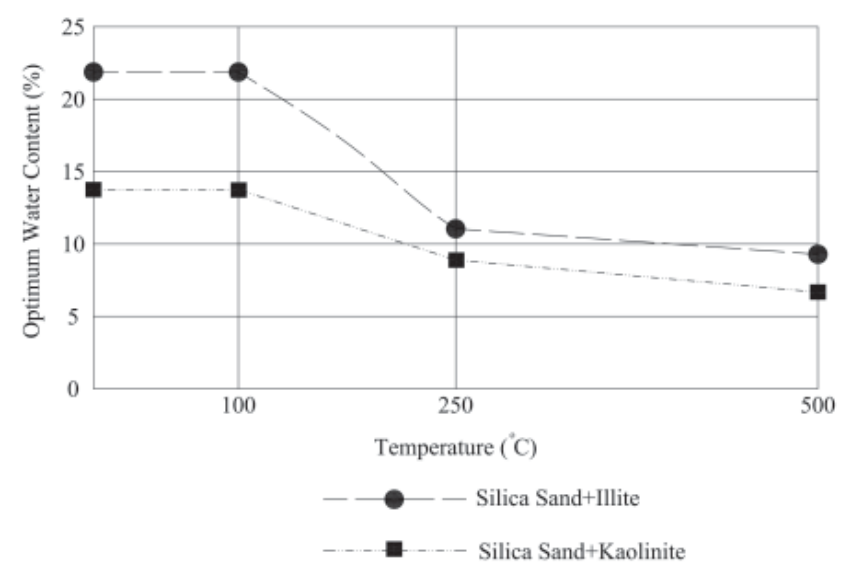

FIGURE 6. Effect of heat treatment on optimum water content

The effect of temperature on the unconfined compressive strength of the two soil samples is shown in Figure 8. Temperature increase beyond $100^{\circ} \mathrm{C}$ produced excessive decrease in unconfined compressive strength for the two soils and finally it reached to $0 \%$ at the temperature of $500^{\circ} \mathrm{C}$.

In previous literature, the study of heat treatment has been mainly focused on illite or kaolinite, where as in this study mixtures of these soils with silica sand were evaluated and compared.

FIGURE 4. Effect of heat treatment on liquid limit 


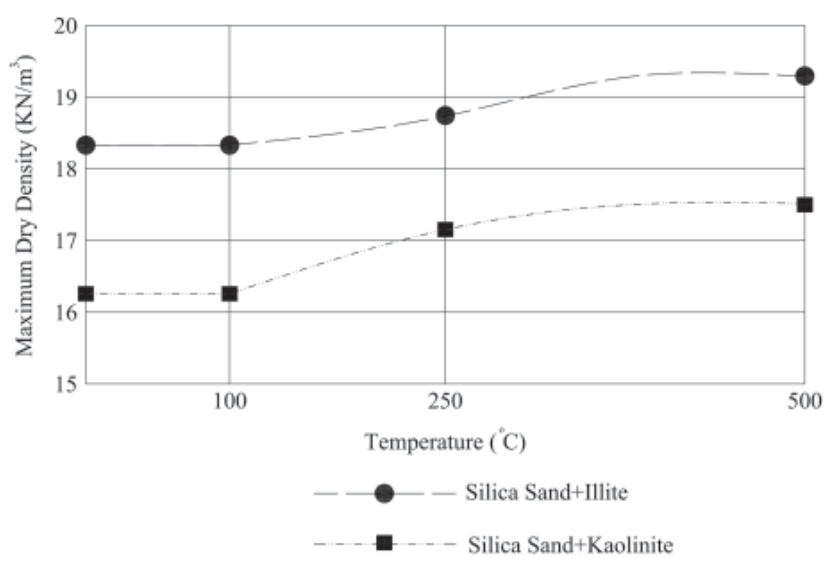

FIGURE 7. Effect of heat treatment on maximum dry density

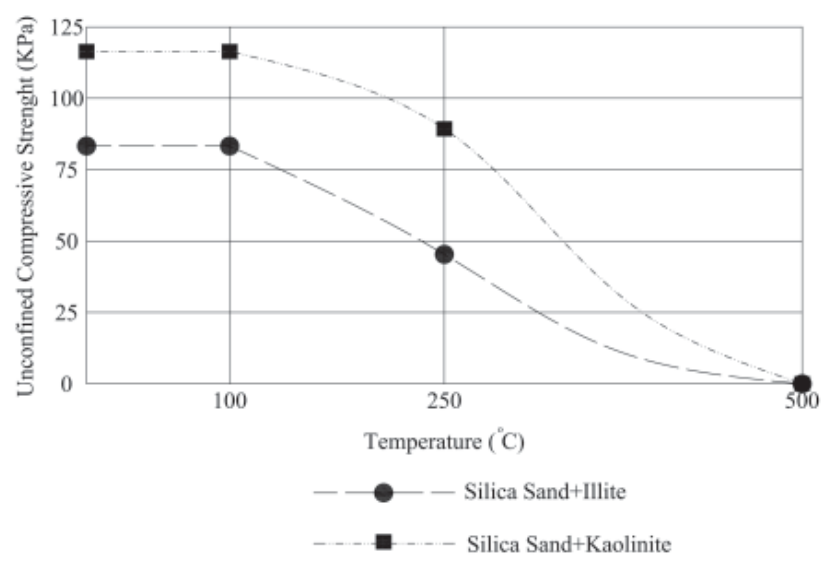

FIGURE 8. Effect of heat treatment on unconfined compressive strength

\section{CONCLUSION}

This study shows that the temperature has a significant effect on soil physical properties such as Atterberg limits, optimum water content and unconfined compressive strength. The relative change in these properties was higher when temperature ranged from 100 to $500^{\circ} \mathrm{C}$. Soils were normally not affected in great deal by temperature below $100^{\circ} \mathrm{C}$. Therefore it can be concluded that a temperature of $500^{\circ} \mathrm{C}$ brings drastic changes in the mechanical properties of the two soils and transforming them into very weak soils.

\section{ACKNOWLEDGEMENT}

We acknowledge and appreciate the financial support and facilities provided by Geotechnical Engineering lab of Universiti Kebangsaan Malaysia (UKM) for this study and Fuel Cell Institute for SEM tests.
REFERENCES

Akinmusuru, J. 1994. Thermal conductivity of earth blocks. Journal of Materials in Civil Engineering 6: 3-341.

Alcocer, C. \& Chowdhury, H. 1993. Experimental study of an environmental remedation of Gulf Coast crudeoil contaminated soil using low-temperature thermal treatment. Proceedings of the 1993 Western Regional Meeting, Louisiana. Society of Petroleum Engineers, Richardson, TX. 723-724.

ASTM D2166. 2006. Standard Test Method for Unconfined Compressive Strength of Cohesive Soil. American Society for Testing and Materials, Building Stones, ASTM, Philadelphia.

ASTM D2216. 2010. Standard Test Methods for Laboratory Determination of Water (Moisture) Content of Soil and Rock by Mass. Annual Book of ASTM Standards, Vol. 04.08, Soil and Rock. American Society for Testing and Materials, Building Stones, ASTM, Philadelphia.

ASTM D4318. 2010. Standard Test Methods for Liquid Limit, Plastic Limit, and Plasticity Index of Soils. Annual Book of ASTM Standards, Vol. 04.08, Soil and Rock. American Society for Testing and Materials, Building Stones, ASTM, Philadelphia.

ASTM D7382.2008. Standard Test Methods for Determination of Maximum Dry Unit Weight and Water Content Range for Effective Compaction of Granular Soils Using a Vibrating Hammer. Annual Book of ASTM Standards, Vol. 04.09, Soil and Rock. American Society for Testing and Materials, Building Stones, ASTM, Philadelphia.

Bayram, H., Önal, M., Yılmaz, H. \& Sarıkaya, Y. 2010. Thermal analysis of a white calcium bentonite. $J$ Therm Anal Calorim 101: 873-879.

Joshi, R., Gopal, A. C., Horsfield, D. \& Nagaraj, T. 1994. Effect of heat treatment on strength of clays, Journal of Geotechnical Engineering 120: 1066-1080.

Ma, C. \& Hueckel, T. 1992. Effects of inter phase mass transfer in heated clays: a mixture theory. International Journal of Engineering Science 30: 11-1567.

Michot, A., Smith, D. S., Degot, S. \& Gault, C. 2008. Thermal conductivity and specific heat of kaolinite: Evolution with thermal treatment. Journal of the European Ceramic Society 28(14): 2639-2644.

Mitchell, J. K. 1969. Temperature effects on the engineering properties and behaviour of soils. Highway Research Board (Special Report): 103.

Tanaka, N., Graham, J. \& Crilly, T. 1997. Stress-strain behavior of reconstituted illite clay at different temperatures, Engineering Geology 47: 339-351.

Vizcayno, C., Gutiérrez, R. M., Castello. R., Rodriguez, E. \& Guerrero, C. E. 2009. Pozzolan obtained by mechanochemical and thermal treatments of kaolin. Journal of the European Ceramic Society 28(14): 26392644. 
William, R. 1997. Burning bush. Fire Engineering 150: 4-11.

Yang, L. \& Arouk, B. 1995. Modelling of solid particles flow and heat transfer in rotary kiln calciners. $30^{\text {th }}$ National Heat Transfer Conference. American Society of Mechanical Engineers. 11-19.

Yang, L. \& Farouk, B. 1995. Modeling of solid particles flow and heat transfer in rotary kiln calciners. Proceedings of the 30th National Heat Transfer Conference, Portland, Oregon. American Society of Mechanical Engineers, New York, NY. 11-19.
A. Akbar Firoozi*, M.R. Taha, A. Asghar Firoozi \& Tanveer A. Khan

Department of Civil \& Structural Engineering Faculty of Engineering and Built Environment Universiti Kebangsaan Malaysia 43600 UKM Bangi, Selangor D.E.

Malaysia

*Corresponding author; email: a.firoozi@gmail.com

Received date: $21^{\text {st }}$ April 2014

Accepted date: $24^{\text {th }}$ July 2014 
